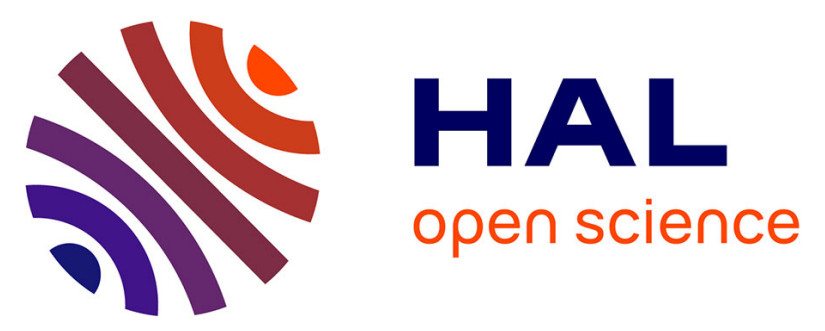

\title{
A time delay artificial neural network approach for flow routing in a river system
}

\author{
M. J. Diamantopoulou, P. E. Georgiou, D. M. Papamichail
}

\section{To cite this version:}

M. J. Diamantopoulou, P. E. Georgiou, D. M. Papamichail. A time delay artificial neural network approach for flow routing in a river system. Hydrology and Earth System Sciences Discussions, 2006, 3 (5), pp.2735-2756. hal-00298765

\section{HAL Id: hal-00298765 \\ https://hal.science/hal-00298765}

Submitted on 12 Sep 2006

HAL is a multi-disciplinary open access archive for the deposit and dissemination of scientific research documents, whether they are published or not. The documents may come from teaching and research institutions in France or abroad, or from public or private research centers.
L'archive ouverte pluridisciplinaire HAL, est destinée au dépôt et à la diffusion de documents scientifiques de niveau recherche, publiés ou non, émanant des établissements d'enseignement et de recherche français ou étrangers, des laboratoires publics ou privés. 
Hydrol. Earth Syst. Sci. Discuss., 3, 2735-2756, 2006 www.hydrol-earth-syst-sci-discuss.net/3/2735/2006/

(C) Author(s) 2006. This work is licensed under a Creative Commons License.
Hydrology and

Earth System

Sciences

Discussions

Papers published in Hydrology and Earth System Sciences Discussions are under open-access review for the journal Hydrology and Earth System Sciences

\section{A time delay artificial neural network approach for flow routing in a river system}

M. J. Diamantopoulou ${ }^{1}$, P. E. Georgiou ${ }^{2}$, and D. M. Papamichail ${ }^{2}$

${ }^{1}$ Faculty of Forestry and Natural Environment, Aristotle University of Thessaloniki, 54124 Thessaloniki, Greece

${ }^{2}$ Department of Hydraulics, Soil Science and Agricultural Engineering, Faculty of Agriculture, Aristotle University of Thessaloniki, 54124 Thessaloniki, Greece

Received: 6 June 2006 - Accepted: 1 September 2006 - Published: 12 September 2006

Correspondence to: D. M. Papamichail (papamich@agro.auth.gr)

HESSD

3, 2735-2756, 2006

A time delay ANN approach for river

flow routing

M. J. Diamantopoulou et

al.

\section{Title Page}

Abstract

Conclusions

Tables

14

4

Back

Full Screen / Esc

Printer-friendly Version

Interactive Discussion 


\section{Abstract}

River flow routing provides basic information on a wide range of problems related to the design and operation of river systems. In this paper, three layer cascade correlation Time Delay Artificial Neural Network (TDANN) models have been developed to 5 forecast the one day ahead daily flow at llarionas station on the Aliakmon river, in Northern Greece. The networks are time lagged feed-formatted with delayed memory processing elements at the input layer. The network topology is using multiple inputs, which include the time lagged daily flow values further up at Siatista station on the Aliakmon river and at Grevena station on the Venetikos river, which is a tributary to the 10 Aliakmon river and a single output, which are the daily flow values at llarionas station. The choice of the input variables introduced to the input layer was based on the crosscorrelation. The use of cross-correlation between the ith input series and the output provides a short cut to the problem of the delayed memory determination. Kalman's learning rule was used to modify the artificial neural network weights. The networks are designed by putting weights between neurons, by using the hyperbolic-tangent function for training. The number of nodes in the hidden layer was determined based on the maximum value of the correlation coefficient. The results show a good performance of the TDANN approach for forecasting the daily flow values, at llarionas station and demonstrate its adequacy and potential for river flow routing. The TDANN approach introduced in this study is sufficiently general and has great potential to be applicable to many hydrological and environmental applications.

\section{Introduction}

River flow forecasting and specifically river flood forecasting is one of the most important components in many flood control systems. Flood forecasting models are becoming very essential tools to forecast future flood events early enough in order to take appropriate control action to minimize damage. There are different types of flood
HESSD

3, 2735-2756, 2006

A time delay ANN approach for river flow routing

M. J. Diamantopoulou et

al.

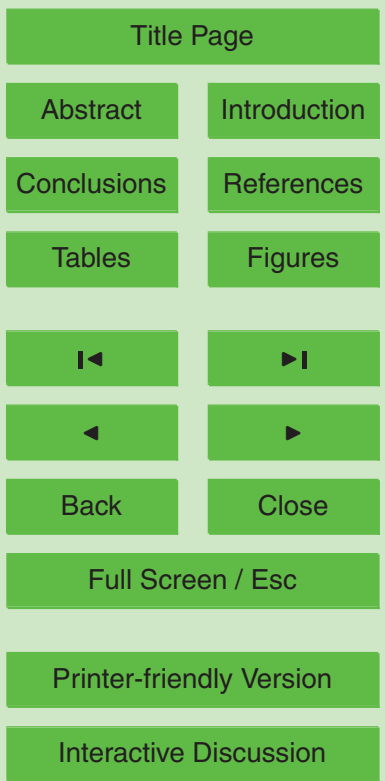


forecasting models, and they can be classified into three types: empirical (or black box) models, lumped conceptual models and distributed physically based models. Black box models may also be divided into sub groups according to their origin, namely empirical hydrological methods (such as unit hydrograph model), statistically based models

5 (such as ARMA, ARMAX, SARIMA (Hipel and McLeod, 1994; Papamichail and Georgiou, 2001) gauge to gauge correlation models etc.) and artificial intelligence based models (such as artificial neural networks).

In recent years, ANN models have become extremely popular for prediction and forecasting in a number of areas, including finance, power generation, medicine, water re10 sources and environmental science (Maier and Dandy, 2000). A number of researchers have investigated the adaptability of ANN models to the field of hydrology, water resources and hydrologic time series (French et al., 1992; Karunanithi et al., 1994; Lorrai and Sechi, 1995; Raman and Sunilcumar, 1995; Maier and Dandy, 1996; Shamseldin et al., 1997; Zhang and Stanley, 1997; Thirumalasah and Deo, 1998; Zealand et al., 15 1999; Anmala et al., 2000; Coulibaly et al., 2000; Govindaraju and Rao, 2000; Islam and Kothari, 2000; Tokar and Markus, 2000; Shamseldin and O'Connor, 2001; Dawson et al., 2002; Loukas et al., 2002; Mantoglou and Kourakos, 2002; Agarwal and Singh, 2004; Shrestha et al., 2005; Kumar et al., 2004; Daliakopoulos et al., 2005; Alvisi et al., 2006).

20 In this paper, three layer cascade correlation Time Delay Artificial Neural Network (TDANN) models were developed to forecast the daily flow at llarionas station on the Aliakmon river by using multiple inputs. These inputs include the time lagged daily flow values further up at Siatista station on the Aliakmon river and at Grevena station on the Venetikos river, which is a tributary to the Aliakmon river.

\section{Artificial neural networks methodology}

Artificial Neural Network is an information processing system that tries to replicate the behavior of a human brain by emulating the operations and connectivity of biological

\section{A time delay ANN approach for river flow routing}

M. J. Diamantopoulou et al.

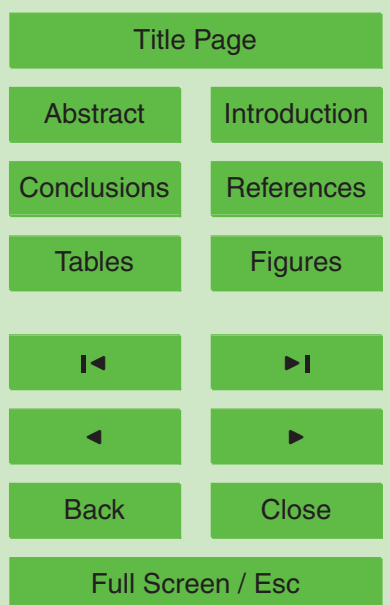

Printer-friendly Version

Interactive Discussion 
neurons (Fausett, 1994). The basic structure of an ANN model, usually, consists of three distinctive layers, the input layer, where the data are introduced to the ANN, the hidden layer or layers, where data are processed, and the output layer, where the results of ANN are produced. The structure and operation of ANNs is discussed by a 5 number of authors (Fausett, 1994; Haykin, 1994; Dowla and Rogers, 1995; Patterson, 1996; Gurney, 1999; Diamantopoulou, 2005).

The ANNs are designed by putting weights between neurons, by using a transfer function that controls the generation of the output in a neuron, and using adjustable laws that define the relative importance of weights for input to a neuron. In the training, 10 the ANN defines the importance of the weights and adjusts them through an iterative procedure.

The training of ANNs suitable for the current application is the cascade correlation algorithm (Fahlman and Lebiere, 1990; Diamantopoulou, 2005), which produces the cascade correlation Time Delay Artificial Neural Network (TDANN) that belongs to the 15 fee feedforward type, which is a supervised algorithm in the multilayer feed-forward ANNs. The Cascade part refers to the architecture and its mode of construction entails adding hidden units once at a time and always connecting all the previous units to the current unit. The Correlation part refers to the way hidden units were trained by trying to maximize the correlation between output of the hidden unit and the desired output of the network across the training data. The training procedure of TDANNs is composed of a forward pass. The information is processed in the forward direction from the input layer to the hidden layer or layers to the output layer. Kalman's learning rule (Brown and Hwang, 1992; Grewal and Andrews, 1993; Masters, 1993; Demuth and Beale, 2001) was used to modify the TDANN weights. Such, a network has the ability to data values and pass them on to the hidden layer nodes. Each one of them collects the input from all inputs nodes after multiplying each input value by a weight, attaches a bias to this sum and passes on the result through a nonlinear transformation, the

HESSD

3, 2735-2756, 2006

\section{A time delay ANN approach for river flow routing}

M. J. Diamantopoulou et al.

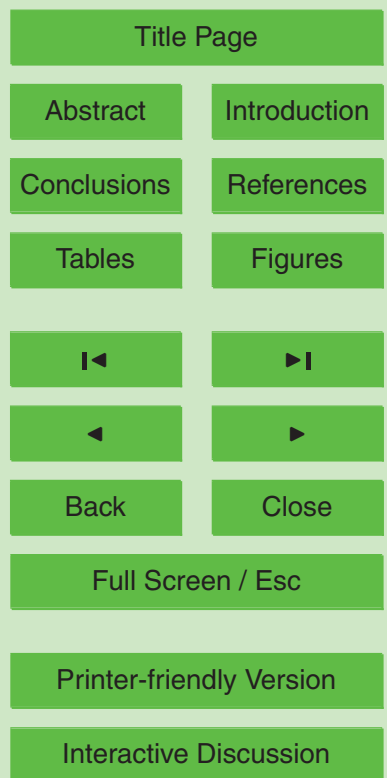


hyperbolic transfer function (Fausett, 1994):

$f(s)=\tanh (s)=\frac{e^{s}-e^{-s}}{e^{s}+e^{-s}}$

HESSD

where: $s=\sum_{i=1}^{n} w_{i} x_{i}$, in which $w_{i}$ are weights and $x_{i}$ are input values, $s \in[-\infty,+\infty]$ and $\tanh (s) \in(-1,+1)$.

Generally, the objective of the training algorithm needed by the network for training, is to reduce the global error $e$ (Eq. 2) (Govindaraju and Rao, 2000) by adjusting the weights and biases.

$e=\frac{1}{P} \sum_{p=1}^{P} e_{p}$

where: $\mathrm{P}$ is the total number of training patterns and $e_{p}$ is the error for the training pattern $p$ defined by:

$e_{p}=\frac{1}{2} \sum_{i}^{n}\left(O_{i}-d_{i}\right)^{2}$

where: $\mathrm{n}$ is the total number of the output nodes, $O_{i}$ is the network output at the $i$ th output node and the $d_{i}$ is the desired target output at the $i$ th output node.

The cascade correlation algorithm starts the training without any hidden nodes. If the error between the network realized output and the target is not small enough, it adds one hidden node. This node is connected to all other nodes except the output nodes. The optimal number of the hidden nodes is commonly determined by trial and error. The approach is to begin without any hidden nodes and train the network, iteratively repeating the process for an increasing number of nodes till no further improvement in network performance is obtained. Because of its dynamic expansion that continues until the problem is successfully learned the cascade correlation algorithm automatically

\section{A time delay ANN approach for river flow routing}

M. J. Diamantopoulou et al.

\section{Title Page}

Abstract Introduction

Conclusions

Tables

References

Figures

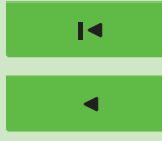

$>1$

Back

Close

Full Screen / Esc

Printer-friendly Version

Interactive Discussion 
consists a suitable algorithm for a given problem (Karunanithi et al., 1994). This procedure goes on until the correlation between the hidden node's output and the residual error of the network, is maximized:

$S=\sum_{O}\left|\sum_{p}\left(v_{p}-\bar{v}\right) \cdot\left(e_{p, O}-\bar{e}_{o}\right)\right|$

5 where: $\mathrm{o}$ is the oth node, $p$ is the $p$ th train pattern, $v_{p}$ is the candidate node's value at $p$ th training pattern, $\bar{v}$ is the average of $v$ over all patterns, $e_{p, o}$ is the residual error observed at node $o$ at $p$ th training patern and $\bar{e}_{o}$ is the average of $e_{p, o}$ over all patterns.

In each training step, a new hidden neuron is added and its weights are adjusted to maximize the magnitude of the correlation. Each hidden neuron is trained just once and then its weights are frozen.

The error between the output of the TDANN and the target value of the output was computed, as well. In order to achieve an estimation of the daily flow at the output station on the river, the time lagged with delayed memory daily flow values further up at a station on the river and at a station on a tributary to the river are introduced as inputs into TDANNs. In this sense, the input layer of TDANNs consists of a number input neurons and one output neuron, which is the daily flow at the output station on the river.

The choice of the input variables introduced to the input layer based on the crosscorrelation. The use of cross-correlation between the ith input series and the output 20 provides a short cut to the problem of the delayed memory determination (Papamichail and Papazafiriou, 1992). The cross-correlation coefficient of the $i$ th input series and the output records on a span of $\mathrm{N}$ times intervals has been given by Yevjevich (1972). As the output increases after the occurrence of the ith input series and then decreases gradually towards to its original level, the cross-correlation coefficient is expected to 25 decrease gradually with increase of the time lag, $\mathrm{k}$. The first minimum positive value of the correlogram approximately indicates the delayed memory. Therefore, personal judgement must be exercised in interpreting the correlogram.

2740
HESSD

3, 2735-2756, 2006

A time delay ANN approach for river flow routing

M. J. Diamantopoulou et al.

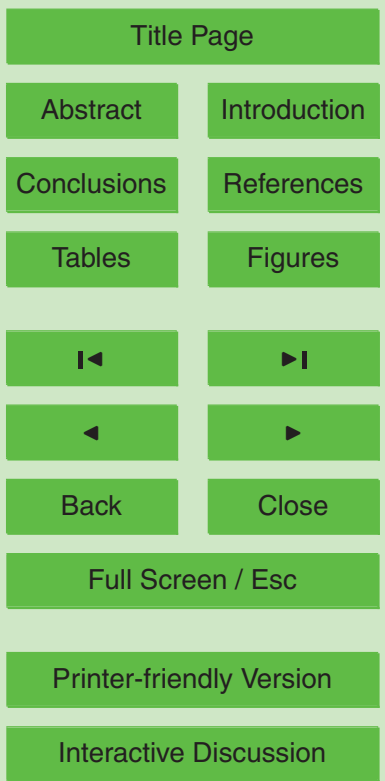

EGU 
During the training of TDANNs in the calibration period, the simulated daily flow values at the output station are compared with the corresponding observed daily flow values to identify the simulation errors. The geometry of TDANNs, which determines the number of connection weights and how these are arranged, depends on the number 5 of hidden layers and the number of the hidden nodes in these layers. In the developed TDANNs, one hidden layer is used and the number of the hidden nodes is optimized by maximizing the correlation between output of the hidden unit and the desired output of the network across the training data. However, the final network architecture and geometry are tested to avoid over-fitting as suggested by Maier and Dandy (2000).

\section{Application and results}

The study area is the Alaikmon river basin, Northern Greece (Fig. 1), between $39^{\circ} 30 \mathrm{~S}$ to $40^{\circ} 30 \mathrm{~N}$ and $20^{\circ} 30 \mathrm{~W}$ to $22^{\circ} \mathrm{E}$. In this paper, TDANN models were developed to forecast the daily flow values at llarionas station on the Aliakmon river by using multiple inputs, which include the time lagged daily flows further up at Siatista station on the 15 Aliakmon river and at Grevena station on the Venetikos river, which is a tributary to the Aliakmon river (Fig. 1). The distance from Siatista to Ilarionas is approximately $100 \mathrm{~km}$. Thus, there are two separate independent input functions of time and a single output function of time.

The TDANN models were developed by using the daily flow data from 1 October 201977 to 30 September 1986 as the calibration period and from 1 October 1986 to 30 September 1987 as the validation period. The daily flow data were obtained from the archives of the Public Power Corporation of Greece. Related information for the three flow stations (Fig. 1) and statistical parameters of their time series of daily flow values for the periods 1977-1986 and 1986-1987, are given in Table 1.

25 For TDANN models construction, daily flow data from 1 October 1977 to 30 September 1986 randomly partitioned into training ( $90 \%$ of all data) and test (the remaining $10 \%$ of all data) data sets, were used. The time lagged daily flows further up at Siatista
HESSD

3, 2735-2756, 2006

A time delay ANN approach for river flow routing

M. J. Diamantopoulou et

al.

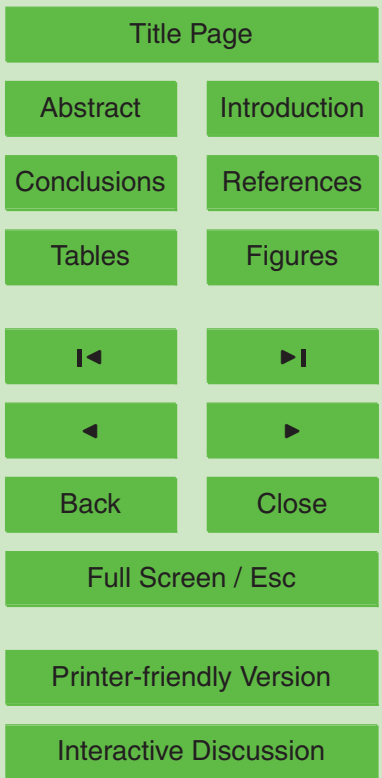


station on the Aliakmon river and at Grevena station on the Venetikos river, which is a tributary to the Aliakmon river, were used as inputs. The delayed memory corresponding to the ith input series was determined by using the cross-correlation between the ith input series and the output. This procedure was applied to the Aliakmon river 5 system (Fig. 1), using daily flow data and the correlograms, between daily flow values at Siatista and Ilarionas and between daily flow values at Grevena and Ilarionas during the calibration period (Fig. 2) indicate that the delayed memory of the system corresponding to the ith input series appears to be equal to 10 days.

Numerous TDANN structures tested in order to determine the optimum number of 10 hidden layers and the number of nodes in each. The architecture of the best TDANN model for Aliakmon river flow routing is composed of one input layer with twenty input variables, one hidden layer with three nodes and one output layer with one output variable. The inputs $Q_{S t}, Q_{S(t-1)}, Q_{S(t-2)}, \ldots, Q_{S(t-9)}$ and $Q_{G t}, Q_{G(t-1)}, Q_{G(t-2)}, \ldots, Q_{G(t-9)}$ represent the delayed daily flows recorded at Siatista and Grevena, respectively. The 15 output $Q$, represents the daily flows forecasted at llarionas station.

The best TDANN model, the correlation coefficient $(R)$, the mean absolute error (MAE), the root mean square error (RMSE), the RMSE (\%) of the mean, between the output of the hidden unit and the desired output of the TDANN model, for the Aliakmon river daily flow routing, for the calibration, the training, the test and the validation data sets, are given in Table 2. The notation (Q, / TDANN: 20-3-1/0.9976) (Table 2) means that the best architecture of the specific TDANN model is composed of one input layer with twenty input variables, one hidden layer with three nodes and one output layer with one output variable, with value of correlation coefficient equals to 0.9976 .

According to the results of Table 2 we can see that the difference in the R, MAE and RMSE obtained using the test data set is not markedly different than that obtained using the training data, meaning there is no overfitting. Also, the results of Table 2 show a good performance of the selected TDANN model for forecasting the daily flow values at llarionas station.

The observed daily flow hydrographs for the three flow stations of the Aliakmon river

\section{HESSD}

3, 2735-2756, 2006

A time delay ANN approach for river flow routing

M. J. Diamantopoulou et al.

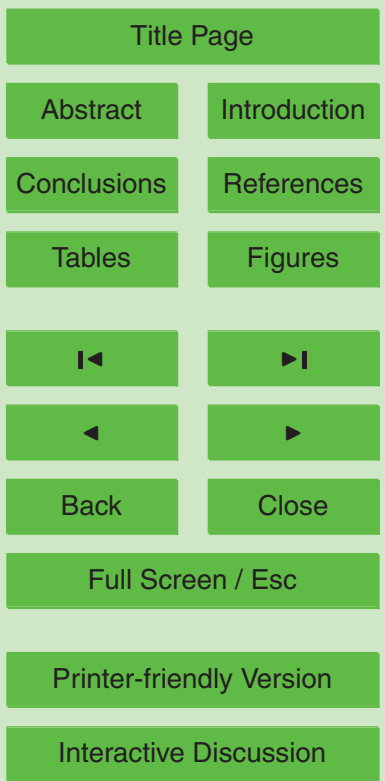


system and the forecasted by the selected TDANN model daily flow hydrograph at Ilarionas station during the calibration period (1 October 1977 to 30 September 1986) and the validation period (1 October 1986 to 30 September 1987) are shown in Figs. 3 and 4 , respectively.

$5 \quad$ The observed daily flow values used as output for the calibration and validation periods were compared with the corresponding values estimated by the selected TDANN model (Table 2). The daily flow forecasts, at llarionas station, by the selected TDANN model versus the observed daily flow values, at llarionas station on the Aliakmon river, are shown in Figs. $5 a$ and $b$, for the calibration and validation periods, respectively.

10 Figures 3, 4, 5a and b show that the observed and forecasted by the TDANN model daily flows, during the calibration and validation periods, match well and the effectiveness of the selected TDANN model is clear.

Table 3 depicts the percentage error in annual peak flow forecasts for the TDANN model during the calibration and validation hydrologic years. The low percentage error 15 in annual peak flow forecasts simply that the TDANN model is able to forecast the peak flows with reasonable accuracy. Also, the times to peak are well forecasted.

An analysis to assess the potential of the selected TDANN model to preserve the statistical properties of the historic flow series reveals that the flow series computed by the TDANN model reproduces the first three statistical moments (i.e. mean, standard deviation and skewness) for the calibration and validation hydrologic years.

The comparisons were also made by using the paired t-test with the two-sided tabular value $(\mathrm{a}=0.05)$ and the 45 -degree line test. The computed $t$-values and the slopes of the selected TDANN model, for the daily flow values, at llarionas station on the Aliakmon river, for the calibration, the training, the test and the validation data sets, are 25 given in Table 4.

The computed t-values of the selected TDANN model were less than two-sided tabular t-values, for the calibration, the training, the test and the validation data sets (Table 4). These imply that there were no significant differences between the observed and the forecasted values. Also, the observed values and the forecasted values yielded
HESSD

3, 2735-2756, 2006

\section{A time delay ANN approach for river flow routing}

M. J. Diamantopoulou et

al.

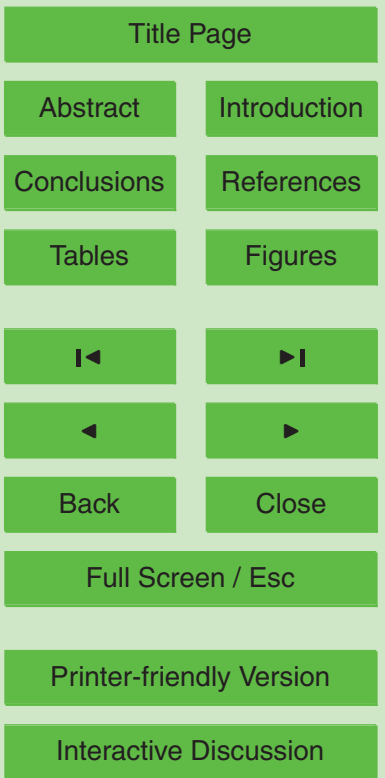


slopes close to 45 degrees, for the calibration, the training, the test and the validation data sets (Table 4). It can be observed that the TDANN model tended to make an angle of 45 degrees with the axes, meaning there is no significant difference between the observed and the computed values. Since the data in the test and validation data 5 sets were never seen by the selected TDANN model, the good forecasting on these data sets (Tables 2, 3 and 4 and Figs. 4 and 5) demonstrated the adequacy and the potential of the selected TDANN model for river daily flow routing.

Tables 2, 3 and 4 and Figs. 3, 4 and 5 clearly demonstrate the ability of the selected TDANN model to forecast very well daily flow values, at llarionas station on the Ali10 akmon river. Consequently, the TDANN models introduced in this study is sufficiently general and seem promising to be applicable for any river flow routing.

\section{Conclusions}

In this paper, Time Delay Artificial Neural Network (TDANN) models were developed for forecasting the daily flow values at llarionas station on the Aliakmon river. The training 15 of the TDANNs was achieved by the cascade correlation algorithm which is a feedforward and supervised algorithm with dynamic expansion. Kalman's learning rule was used to modify the artificial neural network weights. The networks are designed by putting weights between neurons, by using the hyperbolic-tangent function for training. The number of nodes in the hidden layer was determined based on the maximum value

of the coefficient of correlation. In the training process, the test data were not used with no way neither using them as part of the training procedure or as part of the decision when to stop training. No fixed number of iterations used as the stopping criterion of the procedure. The choice of the input variables introduced to the input layer based on the cross-correlation. The use of cross-correlation between the ith input series and the output during the calibration period provides a short cut to the problem of the delayed memory determination. The results, for the training, the test, the calibration and the validation data sets clearly demonstrate the ability of the TDANN models for river daily

\section{HESSD}

3, 2735-2756, 2006

A time delay ANN approach for river flow routing

M. J. Diamantopoulou et al.

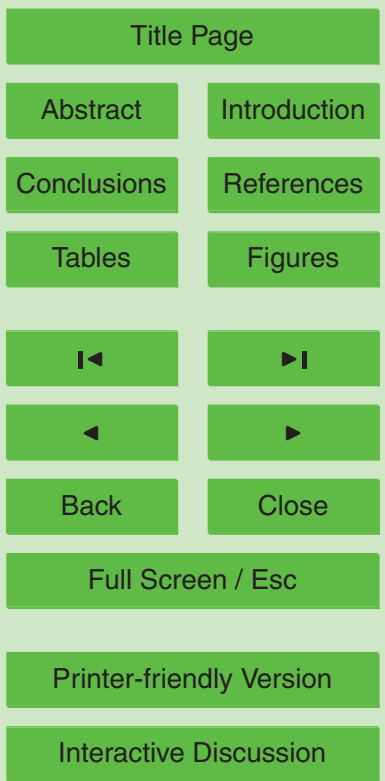

EGU 
flow routing. The TDANN models introduced in this study have the ability to forecast the peak flows with reasonable accuracy, to develop a generalised solution as there is no overfitting and to overcome the problems in data of daily flows in rivers such as outliers and noise in the data. Since the proposed methodology is based on the information 5 contained in the data series itself, the TDANN approach becomes more explicit and can be adopted for any river flow routing. The TDANN approach introduced in this study is sufficiently general and has great potential to be applicable to many hydrological and environmental applications.

\section{References}

10 Agarwal, J. and Singh, R. D.: Runoff modelling through back propagation artificial neural networks with variable rainfall-runoff data, Water Resour. Manage., 18, 285-300, 2004.

Alvisi, S., Mascellani, G., Franchini, M., and Bardossy, A.: Water level forecasting through fuzzy logic and artificial neural network approaches, Hydrol. Earth Syst. Sci., 10, 1-17, 2006.

Anmala, J., Zhang, B., and Govindaraju, R. S.: Comparison of ANNs and empirical approaches for predicting watershed runoff, J. Water Resour. Planning Manage., 126, 156-166, 2000.

Brown, R. G. and Hwang, P. Y. C.: Introduction to random signals and applied Kalman filtering, 2nd Ed., Wiley, New York, 1992.

Coulibaly, P., Anctil, F., and Bobbe, B.: Daily reservoir inflow forecasting using artificial neural networks with stopped training approach, J. Hydrol., 230, 244-257, 2000.

Daliakopoulos, I. N., Coulibaly, P., and Tsanis, I. K.: Groundwater level forecasting using artificial neural networks, J. Hydrol., 309, 229-240, 2005.

Dawson, C. W., Harpham, C., Wilby, R. L., and Chen, Y.: Evaluation of artificial neural network techniques for flow forecasting in the River Yangtze, China, Hydrol. Earth Syst. Sci., 6, 619626, 2002.

25 Demuth, H. and Beale, M.: Neural network toolbox. For use with Matlab ${ }^{\circledR}$, User's Guide, V4, 2001.

Diamantopoulou, M.: Artificial neural networks as an alternative tool in pine bark volume estimation, Comput. Electron. Agric., 48, 235-244, 2005.

\section{A time delay ANN approach for river flow routing}

M. J. Diamantopoulou et al.

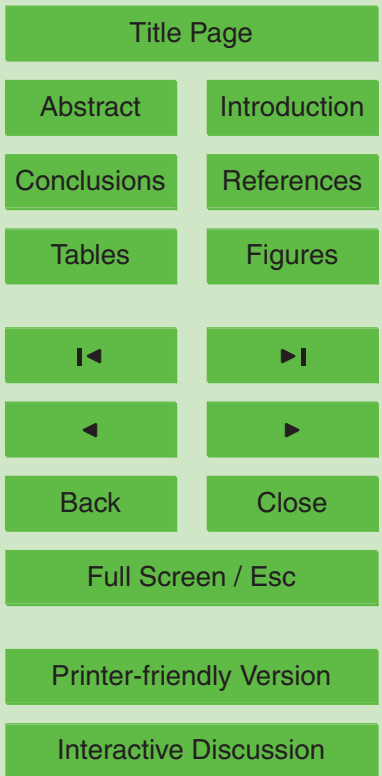


Dowla, U. F. and Rogers, L.: Solving problems in environmental engineering and geosciences with artificial neural networks, Massachusetts, USA, 1995.

Fahlman, S. E. and Lebiere, C.: The cascade correlation learning architecture, in: Advances in Neural Information Processing Systems 2, edited by: Touretsky, D. S., San Mateo, CA, Morgan Kaufmann, 524-532, 1990.

Fausett, L.: Fundamentals of neural networks architectures, Algorithms and applications, Prentice Hall, USA, 1994.

French, M. N., Krajeswski, W. F., and Cuykendall, R. R.: Rainfall forecasting in space and time using a neural network, J. Hydrol., 137, 1-31, 1992.

10 Govindaraju, R. S. and Rao, A. R.: Artificial neural networks in hydrology, Kluwer Academic Publishers, Amsterdam, 2000.

Grewal, M. S. and Andrews, A. P.: Kalman filtering theory and practice, Upper Saddle River, Prentice Hall, NJ, USA, 1993.

Gurney, K.: An introduction to neural networks, UCL Press, UK, 1999.

15 Haykin, S.: Neural networks: A comprehensive foundation, Macmillan, New York, USA, 1994.

Hipel, K. W. and McLeod, A. I.: Time series modelling of water resources and environmental systems, Elsevier Science B.V., Development in Water Science, No. 45, 1994.

Islam, S. and Kothari, R.: Artificial neural networks in remote sensing of hydrologic processes, J. Hydrol. Eng., 5, 138-144, 2000.

20 Kumar, D. N, Raju, K. S., and Sathish, T.: River flow forecasting using recurrent neural networks, Water Resour. Manage., 18, 143-161, 2004.

Karunanithi, N., Grenmey, W. J., Whitley, D., and Bovee, K.: Neural networks for river flow forecasting, J. Comp. Civil Eng., 8, 201-218, 1994.

Lorrai, M. and Sechi, G. M.: Neural nets for modelling rainfall-runoff transformations, Water Resour. Manage., 9, 299-313, 1995.

Loukas, A., Vasiliades, L., and Dalezios, N.: A hydrologic modeling procedure using a watershed model and artificial neural networks, Proc. of Inter. Conf., Water Resources Management in the ERA of Transition, European Water Resources Association, Athens, 219-228, 2002.

30 Maier, H. R. and Dandy, G. C.: The use of artificial neural networks for the prediction of water quality parameters, Water Resour. Res., 32, 1013-1022, 1996.

Maier, H. R. and Dandy, G. C.: Neural Networks for the prediction and forecasting of water resources variables: a review of modeling issues and applications, Environ. Model. Soft., 15,

HESSD

3, 2735-2756, 2006

\section{A time delay ANN approach for river flow routing}

M. J. Diamantopoulou et al.

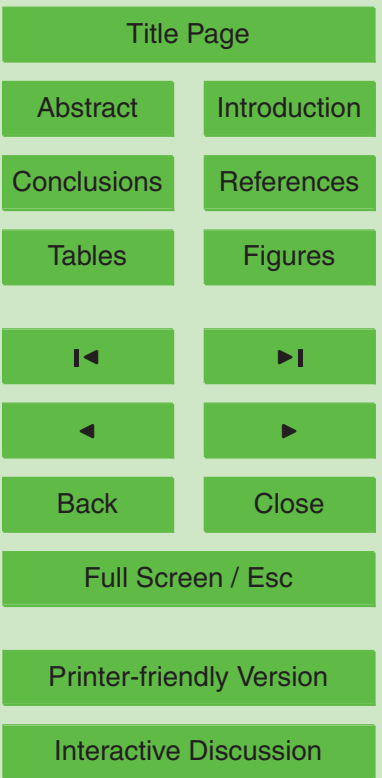

EGU 
101-124, 2000.

Mantoglou, A. and Kourakos, G.: Modeling the rainfall-runoff process using neural networks with emphasis on optimization of network configuration using genetic algorithms, Proc. of Inter. Conf., Water Resources Management in the ERA of Transition, European Water Resources Association, Athens, 229-242, 2002.

Masters, T.: Practical neural networks Recipes in $\mathrm{C}^{++}$, Academic Press, San Diego, CA, 1993.

Papamichail, D. M. and Georgiou, P. E.: Seasonal ARIMA inflow models for reservoir sizing, J. Am. Water Resour. Assoc., 37, 877-885, 2001.

Papamichail, D. M. and Papazafiriou, Z. G.: Multiple input-single output linear functional models for river flow routing, J. Hydrol., 133, 365-377, 1992.

Patterson, D.: Artificial neural networks, Prentice Hall, Singapure, 1996.

Raman, H. and Sunilkumar, N.: Multivariate modelling of water resources time series using artificial neural networks, Hydrol. Sci. J., 40, 145-163, 1995.

Shamseldin, A. Y. and O'Connor, K. M.: A non-linear neural network technique for updating of river flow forecasts, Hydrol. Earth Syst. Sci., 5, 577-597, 2001.

Shamseldin, A. Y., O'Connor, K. M., and Liang, G. C.: Methods for combining the outputs of different rainfall-runoff models, J. Hydrol., 197, 203-229, 1997.

Shrestha, R. R., Theobald, S., and Nestmann, F.: Simulation of flood flow in a river system using artificial neural networks, Hydrol. Earth Syst. Sci., 9, 313-321, 2005.

20

Thirumalaiash, K. and Deo, M. C.: River stage forecasting using artificial neural networks, J. Hydrol. Eng., 3, 26-32, 1998.

Tokar, A. S. and Markus, M.: Precipitation- runoff modelling using artificial neural networks and conceptual models, J. Hydrol. Eng., 5, 156-161, 2000.

Yevjevich, V.: Stochastic processes in hydrology, Water Resources Publications, Fort Collins, 25 CO, 1972.

Zealand, C. M., Burn, D. H., and Simonovic, S. P.: Short tern streamflow forecasting using artificial neural networks, J. of Hydrol., 214, 32-48, 1999.

Zhang, Q. and Stanley, S. J.: Forecasting raw-water quality parameters for the North Saskatchewan river by neural network modelling, Water Res., 31, 2340-2350, 1997.

\section{HESSD}

3, 2735-2756, 2006

\section{A time delay ANN approach for river flow routing}

M. J. Diamantopoulou et al.

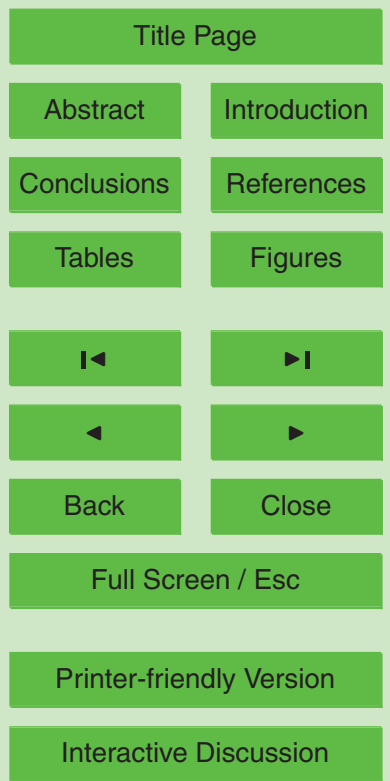


Table 1. Related information for the three flow stations and statistical parameters of their time series of daily flow values for the calibration period 1977-1986 and the validation period 19861987.

\begin{tabular}{|c|c|c|c|c|c|}
\hline \multicolumn{6}{|c|}{ Aliakmon river at Ilarionas station } \\
\hline $\begin{array}{l}\text { Basin } \\
\text { area } \\
\left(\mathrm{km}^{2}\right)\end{array}$ & Time periods & $\begin{array}{l}\text { Mean } \\
\left(\mathrm{m}^{3} / \mathrm{s}\right)\end{array}$ & $\begin{array}{l}\operatorname{Min} \\
\left(\mathrm{m}^{3} / \mathrm{s}\right)\end{array}$ & $\begin{array}{l}\operatorname{Max} \\
\left(\mathrm{m}^{3} / \mathrm{s}\right)\end{array}$ & $\begin{array}{l}\text { St. dev. } \\
\left(\mathrm{m}^{3} / \mathrm{s}\right)\end{array}$ \\
\hline \multirow[t]{2}{*}{5005} & $\begin{array}{l}\text { 01 Oct 1977-30 Sept } 1986 \\
\text { (Calibration) }\end{array}$ & 49.21 & 2.11 & 1145.0 & 62.73 \\
\hline & $\begin{array}{l}\text { 01 Oct 1986-30 Sept } 1987 \\
\text { (Validation) }\end{array}$ & 46.82 & 3.05 & 793.0 & 76.91 \\
\hline \multicolumn{6}{|c|}{ Aliakmon river at Siatista station } \\
\hline \multirow[t]{2}{*}{2724.6} & $\begin{array}{l}01 \text { Oct 1977-30 Sept } 1986 \\
\text { (Calibration) }\end{array}$ & 22.78 & 0.28 & 410.60 & 27.12 \\
\hline & $\begin{array}{l}01 \text { Oct } 1986-30 \text { Sept } 1987 \\
\text { (Validation) }\end{array}$ & 20.97 & 1.35 & 330.00 & 33.96 \\
\hline \multicolumn{6}{|c|}{ Venetikos tributary river at Grevena station } \\
\hline \multirow[t]{2}{*}{817.7} & $\begin{array}{l}\text { 01 Oct 1977-30 Sept } 1986 \\
\text { (Calibration) }\end{array}$ & 18.84 & 0.75 & 353.20 & 27.27 \\
\hline & $\begin{array}{l}01 \text { Oct 1986-30 Sept } 1987 \\
\text { (Validation) }\end{array}$ & 18.91 & 0.83 & 206.00 & 27.89 \\
\hline
\end{tabular}

HESSD

3, 2735-2756, 2006

\section{A time delay ANN approach for river \\ flow routing}

M. J. Diamantopoulou et al.

\section{Title Page}

Abstract Introduction

Conclusions

References

Tables

Figures

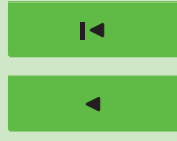

$>1$

Back

Close

Printer-friendly Version

Interactive Discussion 


\section{HESSD}

3, 2735-2756, 2006

\section{A time delay ANN approach for river \\ flow routing}

Table 2. TDANN model, Correlation coefficient (R), Mean absolute error (MAE), Root mean square error (RMSE) and the (\%) of the mean of the TDANN model, at llarionas station, for the Aliakmon river daily flow routing, for the calibration, the training, the test and the validation data sets.

Q// TDANN: 20-3-1/0.9976

\begin{tabular}{llll}
\hline Data & $\mathrm{R}$ & $\mathrm{MAE}$ & $\mathrm{RMSE}$ \\
\hline Calibration (3287) (01 Oct 1977-30 Sept 86) & 0.9976 & 2.23 & $3.68(7.48 \%)$ \\
Train (2958) & 0.9979 & 2.15 & $3.38(6.85 \%)$ \\
Test (329) & 0.9960 & 2.92 & $4.79(9.73 \%)$ \\
Validation (365) (01 Oct 1986-30 Sept 87) & 0.9903 & 1.38 & $6.76(14.4 \%)$ \\
\hline
\end{tabular}

M. J. Diamantopoulou et

al.

Title Page

Abstract Introduction

Conclusions

References

Tables

Figures

14

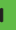

Back

Close

Full Screen / Esc

Printer-friendly Version

Interactive Discussion 


\section{HESSD}

3, 2735-2756, 2006

Table 3. Percentage error in annual peak forecasting for the TDANN model during the calibration and validation hydrologic years.

\begin{tabular}{llcl}
\hline \multicolumn{3}{c}{ Calibration Period } \\
\hline \multirow{3}{*}{ Year } & \multicolumn{3}{c}{ Peak flow $\left(\mathrm{m}^{3} / \mathrm{sec}\right)$} \\
\cline { 2 - 3 } & Historical & TDANN & \\
\hline $1977-78$ & 463.0 & 486.3 & 5.04 \\
$1978-79$ & 727.0 & 689.0 & -5.23 \\
$1979-80$ & 1145.0 & 1120.0 & -2.18 \\
$1980-81$ & 305.0 & 303.0 & -0.65 \\
$1981-82$ & 522.0 & 570.3 & 9.24 \\
$1982-83$ & 427.0 & 430.3 & 0.76 \\
$1983-84$ & 358.0 & 360.5 & 0.69 \\
$1984-85$ & 697.0 & 640.2 & -8.14 \\
$1985-86$ & 515.0 & 550.2 & 6.84 \\
\hline \multicolumn{5}{c}{ Validation Period } \\
\hline $1986-87$ & 793.0 & 740.0 \\
\hline
\end{tabular}

\section{A time delay ANN approach for river \\ flow routing}

M. J. Diamantopoulou et al.

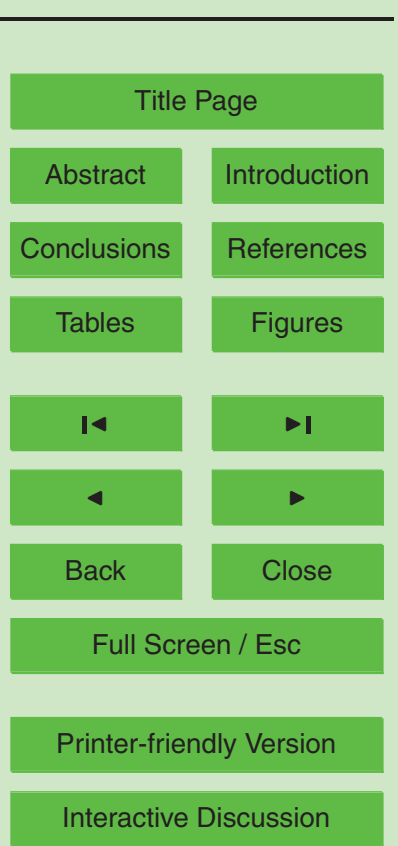




\section{HESSD}

3, 2735-2756, 2006

\section{A time delay ANN approach for river \\ flow routing}

Table 4. $t$-value, two-sided tabular value $(a=0.05)$ and slope of the TDANN model, for the daily flow values at llarionas station, for the calibration, training, test and validation data sets.

\section{Q/ TDANN: 20-3-1/0.9976}

\begin{tabular}{lllll}
\hline Sample size & & t-value & $\begin{array}{l}\text { Two-sided tabular } \\
\text { value }(\mathrm{a}=0.05)\end{array}$ & Slope $\left(^{\circ}\right)$ \\
\hline Calibration (3287) & (01 Oct 1977-30 Sept & 1.548 & 1.961 & 44.54 \\
1986) & & & & \\
Train (2958) & & 1.025 & 1.961 & 44.34 \\
Test (329) & & 1.127 & 1.967 & 45.93 \\
Validation (365) (01 Oct 1986-30 Sept 1987) & 1.692 & 1.966 & 46.02 \\
\hline
\end{tabular}

M. J. Diamantopoulou et

al.

\section{Title Page}

Abstract Introduction

Conclusions

References

Tables

Figures

14

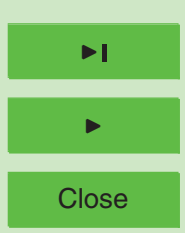

Back

Full Screen / Esc

Printer-friendly Version

Interactive Discussion 


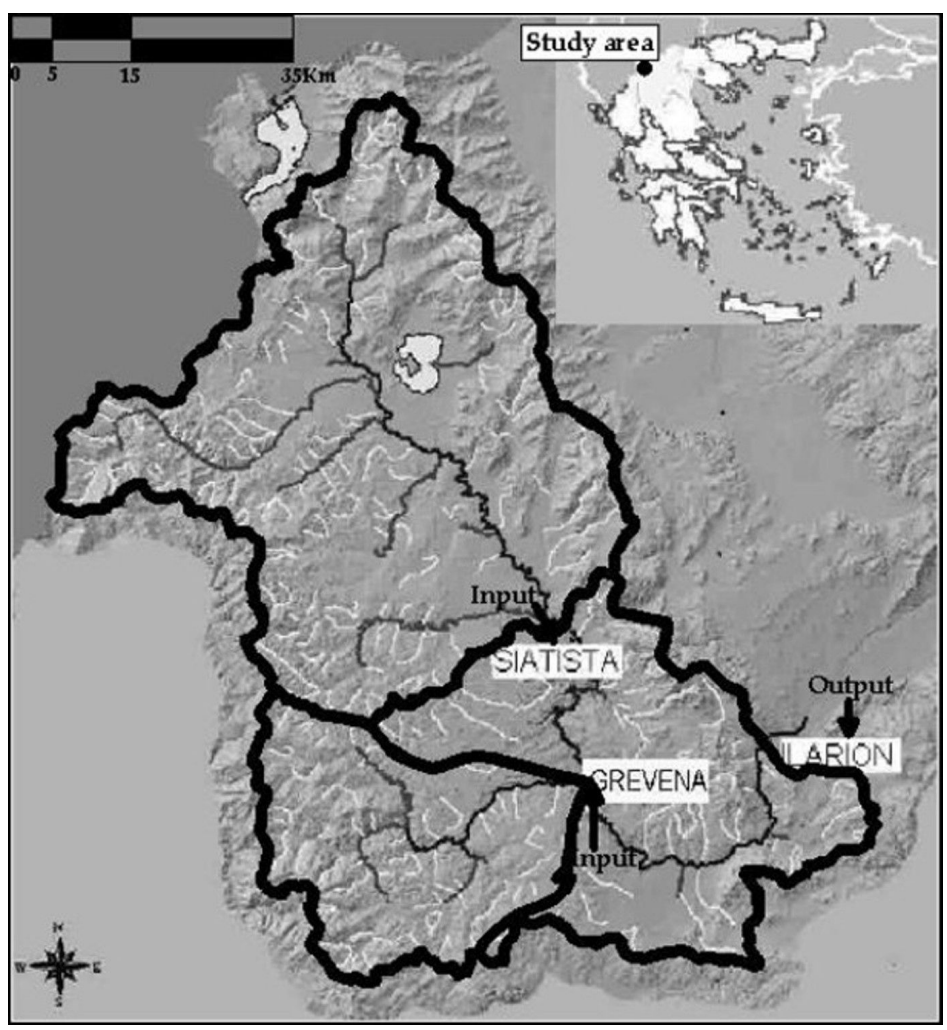

Fig. 1. Map showing the Aliakmon river system.

\section{HESSD}

3, 2735-2756, 2006

A time delay ANN approach for river

flow routing

M. J. Diamantopoulou et al.

Title Page

Abstract

Introduction

Conclusions

References

Tables

Figures

14

4

Back

Full Screen / Esc

Printer-friendly Version

Interactive Discussion 


\section{HESSD}

3, 2735-2756, 2006

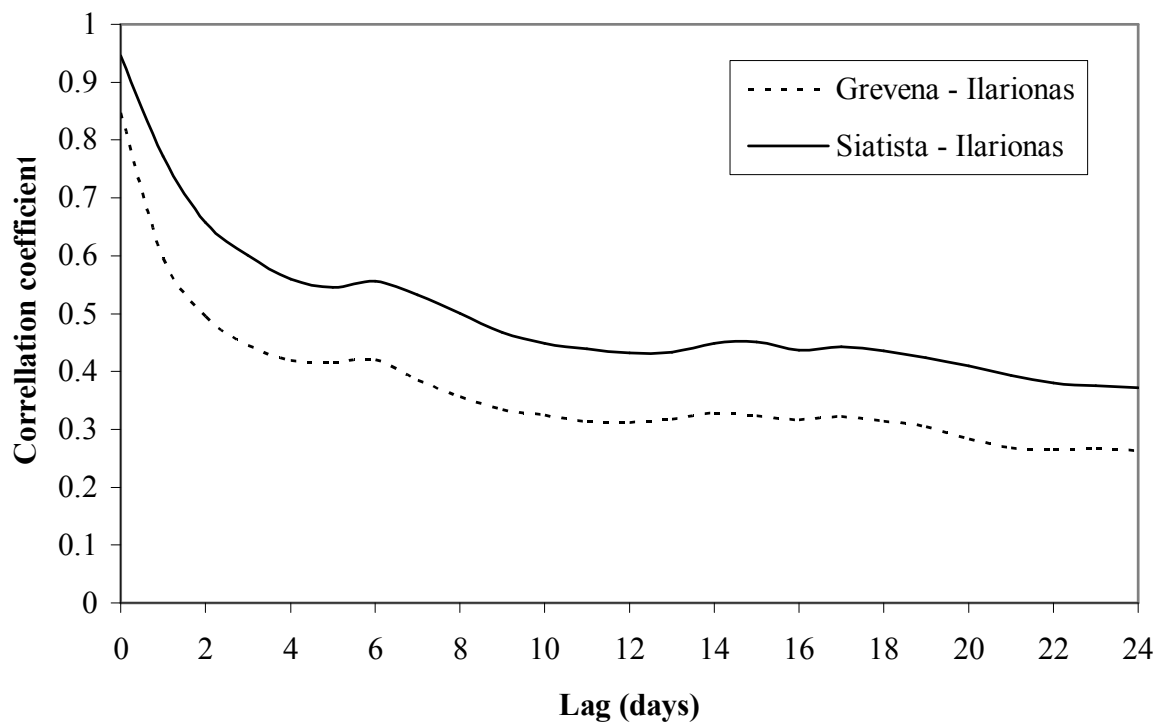

A time delay ANN approach for river flow routing

M. J. Diamantopoulou et al.

Title Page

Abstract Introduction

Conclusions

References

Tables

Figures

14

$\rightarrow$ I

4

Back

Close

Full Screen / Esc

Printer-friendly Version

Interactive Discussion 


\section{HESSD}

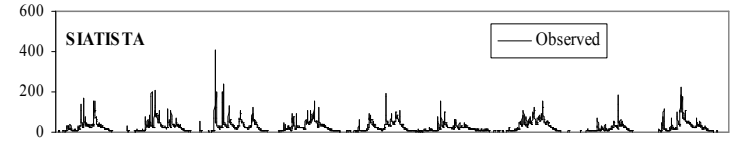

3, 2735-2756, 2006
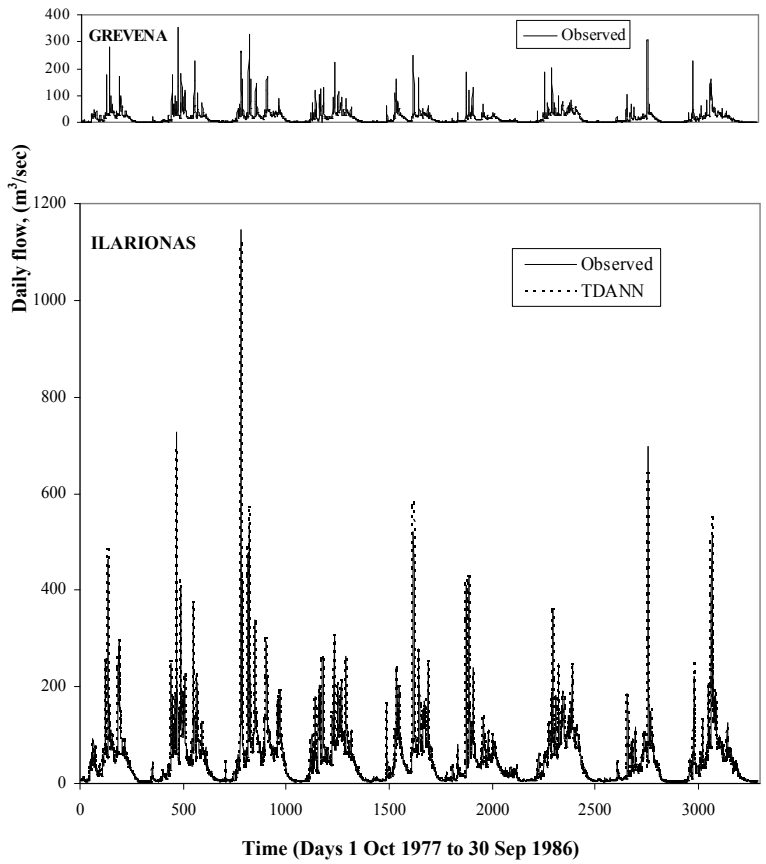

\section{A time delay ANN approach for river flow routing}

M. J. Diamantopoulou et al.

\section{Title Page}

\section{Abstract}

Conclusions

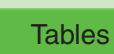

14

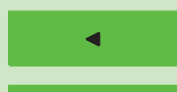

Back
Introduction

References

Figures

$\rightarrow$

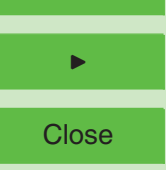

Full Screen / Esc

Fig. 3. Observed and estimated by the TDANN model daily flow hydrographs of the Aliakmon river system during the calibration period. 


\section{HESSD}
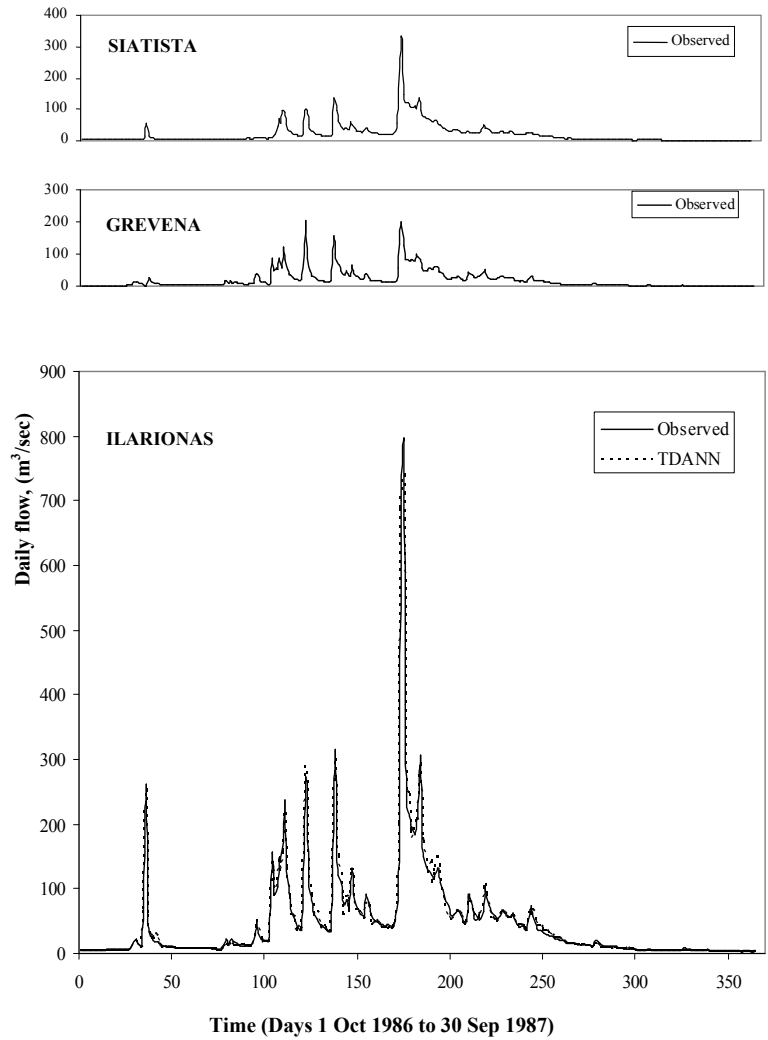

Fig. 4. Observed and forecasted by the TDANN model daily flow hydrographs of the Aliakmon river system during the validation period.
3, 2735-2756, 2006

\section{A time delay ANN} approach for river

flow routing

M. J. Diamantopoulou et

al.

\section{Title Page}

Abstract

Introduction

Conclusions

References

Tables

Figures

14

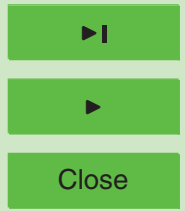

Back

Full Screen / Esc

Printer-friendly Version

Interactive Discussion 


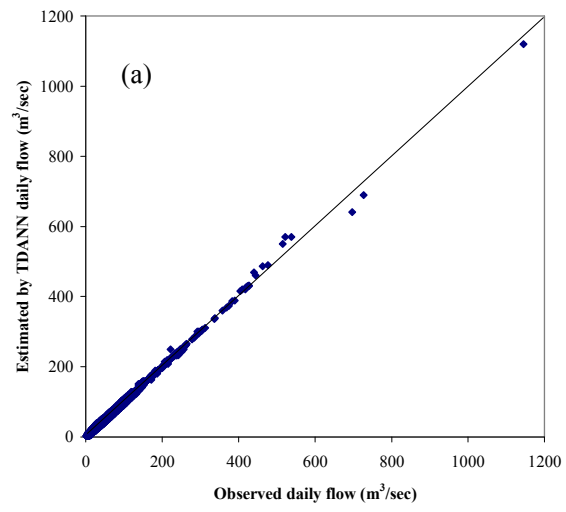

\section{HESSD}

3, 2735-2756, 2006

\section{A time delay ANN approach for river \\ flow routing}

M. J. Diamantopoulou et

al.

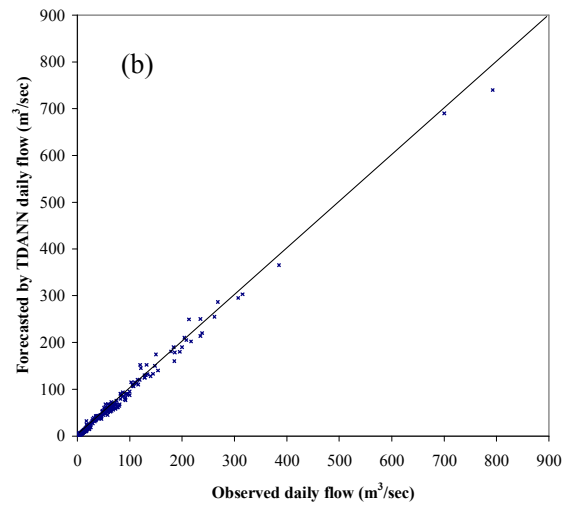

Title Page

Abstract Introduction

Conclusions

References

Tables

Figures

14

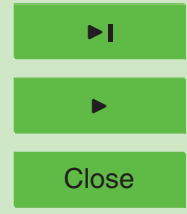

Back

Full Screen / Esc

Printer-friendly Version

Fig. 5. Daily flow forecasts by the TDANN model versus the corresponding observed daily flow

Interactive Discussion validation data set (b). 